\title{
Awareness and Perception of Muslim Consumers on Non-Food Halal Product
}

\author{
*Norafni Farlina Rahim, Zurina Shafii, Syahidawati Shahwan \\ Universiti Sains Islam Malaysia, Nilai, Negeri Sembilan, Malaysia \\ *farlina_84@yahoo.com
}

\begin{abstract}
Halal has become the lifestyle of Muslim consumers in the world. As the Muslim populations increasing throughout the world, the awareness on consuming Halal also goes in the same parallel trend. In Malaysia, Halal food certification and management are given a lot of attention by the consumers, producers and regulators. However, Halal is not only covering only food consumption but also for nonfood products such as cosmetics, toiletries, pharmaceuticals, leather products, perfume and fragrances, brushes and so on. The services such as banking, entertainment, tourism, and logistic also related to Halal requirements. Thus, this research paper aims to investigate the awareness and perception of Muslim consumers on non-food Halal products and to identify the factors that influence the awareness and perception of consumers to the non-food Halal products. Moreover, this research also aims to confirm whether the identified variables have the strong influence to the level of awareness and perception of Muslim consumers on non-food Halal product. The samples of the research consisted of 236 government servants in the state of Selangor. The data are collected through questionnaire and analysed using the descriptive statistics, factor analysis and multiple regression. The results of the study revealed that the factors derived from factor analysis are: Halal information $\left(\mathrm{X}_{1}\right)$, Availability $\left(\mathrm{X}_{2}\right)$, Halal on media $\left(\mathrm{X}_{3}\right)$ and Halal programmes $\left(\mathrm{X}_{4}\right)$. Based on correlation and regression analysis, it is predicted that all factors are significant except for Halal programmes $\left(\mathrm{X}_{4}\right)$. This study implicates that Halal-related programmes by related organisations in Halal industry is still lacking in promoting the Halal awareness and perception on non-food products.
\end{abstract}

Keywords: Halal, Halal product, non-food Halal, government servant, factors of awareness and perception

\section{Introduction}

Muslim population all over the world now are nearly 2 billion. Report by IrfanSungkar in Halal Journal (May \& June, 2009) estimated the Muslims in the world now is 1.73 billion and it will be increased by 1.85 billion in 2010. Kettani (2010) in his proceeding paper "2010 World Muslim Population" estimated that Muslim population in 2010 is 1.65 billion.

Table 1: 2010 Estimate of the World Muslim Population

\begin{tabular}{lllll}
\hline Continent & Population & Muslim (\%) & Muslims & Muslim Ratio(\%) \\
\hline Asia & $4,184,149,728$ & 27.44 & $1,148,173,347$ & 69.38 \\
Africa & $1,031,761,881$ & 43.33 & $447,042,815$ & 27.01 \\
Europe & $734,602,633$ & 6.74 & $49,545,642$ & 2.99 \\
Americas & $939,510,388$ & 1.03 & $9,704,062$ & 0.59 \\
Oceania & $35,799,477$ & 1.33 & 475,708 & 0.03 \\
World & $6,925,824,107$ & 23.90 & $1,654,941,394$ & 100 \\
APGR \% & 1.194 & & 1.705 & \\
\hline
\end{tabular}

Source: Kettani (2010)

From Table 1, it is estimated that Muslims in 222 countries are 1.65 billion with the largest Muslim population is in Asia continent which amounting 69 percent out of total Muslim in the world. It is followed by Africa continent which have 27 percent of Muslims. Table 1 also shows that the Muslim population in the world is getting bigger. Not to mention, the population growth of Muslims in the world is estimated to increase by $1.705 \%$ annually (Kettani, 2010). Thus, it creates more demand and larger consumption of Halal products, including food, non-food product and services. In addition, the Muslim nowadays has greater awareness in getting Halal food, products and services. It became a lifestyle and culture for a Muslim world where every single consumer product is needed to legally permit by Shari'ah for consumption such as meat, poultry, raw food, cosmetics, pharmaceuticals, hospitality, insurance, finance, banking, tourism, supply chain and many more. The creation of high demand and larger 
consumption of Muslim in the world is divided in two market segments which are the Muslim majority countries and Muslim minority countries. These market segments make up to $20 \%$ of the world population (Hunter, 2012). According to the estimates revealed by Central Intelligence Agency (CIA) in 2004, Muslims is the second largest community in the world after Christians (Hisyam, 2006).By 2010, as the global Muslim population increase by $2.5 \%$ annually ,the same goes to the expected demand of Halal food and non-food Halal products and it is expected to achieve USD 2.1trillion or RM36.2 trillion a year (Abdul Aziz et al., 2010 and New Straits Times, May 13, 2008).

A research conducted by World Halal Forum Secretariat estimating that global Halal products is amounting USD 2.3 trillion (excluding banking), and 67 percent (USD 1.4 trillion) of this market is comprised of food and beverages. USD 506 billion is from pharmaceuticals and USD 230 billion is made from cosmetics and pharmaceuticals (The Halal Journal, July \& August 2010). Prime Minister Datuk Seri MohdNajibTunRazak said at the $5^{\text {th }}$ World Halal Forum 2010 that the cosmetics and personal care is amounting up to USD 230 billion while pharmaceuticals compose sales up to USD 506 billion (The Borneo Post, June 22, 2010). These shows that the non-food sector is beginning to capture the world Halal market and it also demonstrate that the non-food sector is just as vital as food sector because of the awareness on seeking Halal in non-food product is rising. International Trade and Industry Deputy Minister, DatukMukhriz Mahathir had quoted the figure from the Institute of Personal Care Science of Australia in his speech at International conference on Halal Cosmetics and Toiletries 2010 and said that "The global cosmetics market is worth USD 334 billion and the global Halal cosmetic market estimated at USD 13 billion." (The Star Online, April 13, 2010). This has confirmed by Hunter (2012) stated that half of the Halal cosmetics sales which totalling up to the estimation USD 5-14 billion are in the Middle East countries, and USD 2.1billion of sales are in Saudi Arabia.

In terms of investment, the statistics has shown that Halal industries have shown the growth in investment of the Halal food and non-food sectors. The approved investments for food and non-food industries (medical devices, pharmaceuticals, cosmetics and toiletries) had doubled from RM 3billion to RM 7.2 billion from 1996 to 2005 (Talib, Zailani \& Zainuddin, 2010). This is a proof that Halal market is not only concern on food but also non-food sectors. Referring to the perception of Muslim consumers today, the term Halal for them only applies to food. Abdul Aziz et al. (2010) said that Halal does not only applicable to food, but also to non-food product like clothing, business transaction, job, monetary, investment and also relationship between human. The same notion also argued by Shaari and MohdAriffin (2010) and Abdul Aziz and Vui (2012) by stating that most of the time, Halal management only associated with food, rather it also covers a lot of areas such as purchase intention, income source, attitude toward advertisement, product, word of mouth and religiosity. In fact, Halal matters covered all consumable products like toiletries, pharmaceuticals, cosmetics and services (Hanzaee and Ramezani, 2011 and Ahmad et al., 2011). This result to the standard setters such as Malaysian Halal Standard (MHS), HACCP and GMP are becoming more stringent toward the food processing plants, hotel operations, pharmacies, cosmetics, and etc. (Abdul Aziz and Vui, 2012). The realms of Halal is becoming wider, with the attention and concentrations shift to the other consumption products and services as the new market to be captured by producers and industrial countries (Esfahani and Shahnazari, 2013). Due to the issues highlighted above, this study aims to investigate the awareness and perception of Muslim consumers on non-food Halal products and to identify the factors that influence the awareness and perception of consumers to the non-food Halal products.

\section{Literature Review}

For non-food product, the complications of the ingredients and derivatives become more complex due to modern technology and scarcity of the natural resources. MS 2200:2008 Islamic Consumer Goods has divided the five (5) main Halal sources of cosmetics and personal care which are animals on land and water, plants and microorganism, land and water, alcohol and synthetic (R\&D JAKIM, SinarRohani, MarchApril 2009). Therefore, the guidelines for non-food product are derived from various sources i.e. Quran, Sunnah (the reported sayings, actions, silent approval and attributes of Prophet Muhammad PBUH), Ijma' (consensus of Muslim scholars or ulama'), Qiyas (analogy derived from Quran), Ijtihad (the personal opinion or judgement from ulama' based on Quran, Sunnah and Ijma')(R\&D JAKIM, SinarRohani, MarchApril 2009). The rulings (hukm) and fatwas are formulated according to Maqasid al-Shariah. Maqasid alShariah or the objectives of Shariah is designed to invite benefits and prevent harm (Al-Mubarak and Osmani, 2009) . The concept of Halal in Islam is closely associated with the concept of Maqasid al- 
Shariah (Ridwan Shah et al., 2008 and Talib, Zailani and Zainuddin, 2010). The concept of Maqasid alShariah is to preserve the followings:

- To preserve the purity of religion

- To preserve life

- To preserve Islamic mentality

- To preserve property

- To preserve future generations

- To maintain self-respect and integrity

Awareness and Perception on Non-food Halal Product: Up to this date, there are very limited studies on non-food Halal product, let alone studies on specific non-food Halal product because it is the new emerging sector after Halal food and Islamic finance (halalfocus.net, 2010 , Swidiet.al.,2010 and TheStarOnline.com, 2010). Such studies are also limited due to interpretation of Halal to the non-food product itself that vary according to schools of thoughts (madzahib) across the regions, for example the use of alcohol (ethanol) as fragrance (Hunter, 2012). Hin Yuen Choy, managing director of Unza, a consumer product manufacturer has said, "A lot is about interpretation. Conservative Muslim may wish to avoid alcohol together." (halalfocus.net as cited by IHIA, 2010). In specific studies in non-food Halal product sector, it shows that consumer goodssuch as cosmetics, personal care (including perfume and toiletries) and pharmaceuticals (nutraceuticals included) are the areas of attention. This has been proven by the initiation of Malaysian Halal Standard in cosmetics, personal care and pharmaceuticals (HDC, 2011). The huge figure of sales and market estimation of these two sectors; a cosmetic cum personal care and pharmaceuticals in media is one of the proofs that Malaysia is now venturing and achieving success in these sectors with experts and specialist in the house.

According to a survey by KasehDia Consultation, there is a low of awareness on Halal cosmetics. However the awareness to get the Halal cosmetic is importantly increasing gradually and the consumer are ready to purchase the Halal cosmetics if they are available in the market. The survey found that approximately 57.6 per cent Muslims in Singapore and 37.7 per cent Muslims in Indonesia are aware on getting Halal cosmetics, and more than half are finding difficulties in searching for Halal cosmetics. The Head of KasehDia Consultation claimed that, "the current level of awareness on Halal cosmetics is still low, but it is definitely increasing." The main problem of low awareness on getting Halal cosmetics is due to the availability of Halal cosmetics in the market, contributed by the difficulties to get access to the raw materials and ingredients that are Halal certified to preserve the Halal integrity (Kamaruzaman, 2008, also cited by Teng \& Wan Jusoh, 2013 and Swidi et al., 2010).

Halal Information: Teng \& Wan Jusoh (2013) found that 89.1 per cent from 578 respondents are aware/know about Halal cosmetics and personal care, while 74.6 per cent of the same respondent is using the Halal cosmetics and personal care. For awareness and knowledge sources, matters like 'heard about that', 'used to heard', 'used to read', 'discuss and tell' comes from personal and impersonal source of information (Teng \& Wan Jusoh, 2013). The updates from the Halal authorities also important so that consumers can check the Halal status every time the hesitancy of Halal status take place. 98 per cent of the 50 consumers in Klang Valley confirmed that it is very important of getting Halal updates from authorities on each Halal status of a manufacturer (Anir et al., 2008).

Availability: The availability is always a concern on the non-food Halal product because it is a new emerging sector on the rise. The Muslim consumers are willing to purchase Halal cosmetics and personal care if the product is available (Kamaruzaman, 2008). The availability of Halal cosmetics in the market is a significant factor in the study of the perception of Halal cosmetics products by Abdul Aziz et al. (2010). The availability of Halal cosmetics in Malaysia has been pioneered by 30 years ago by Unza under brand name Safi (Swidi et al., 2010 and IHIA, 2010). Safi has produced a lot of personal care range like shower cream, fragrance, toothpaste, deodorants, and many more. To be certified Halal, the source materials or raw materials of the products also should be Halal-certified.

Halal on Media: Media coverage in this study comprises the matter of the source of information on Halal product which consist of all media available such as television, radio, internet, banner/billboard/outdoor display, magazines, posters, brochures, bulletin, newspaper, documentaries, articles, advertisement, sales promotion and so on (Che Omar, 2013; Rahim \& Pawanteh, 2009; Ayanwale et al., 2005; TheStarBiz, 2012). MohdAmri Abdullah, Deputy Director of JAKIM Halal Hub said that the spreading information 
about Halal concepts and its significance should be circulated in Halal website, dialogues, seminars, foreign embassy, foreign Islamic organizations and dissemination in media (Hassan, 2010). Not only promulgate awareness on Halal product to consumer, promotion also has significant relationship with the awareness related to the intention to buy Halal product (Abdul Aziz and Vui, 2012).Consumers are practically influenced by what they saw in television and Internet that drive their purchasing decision (Swidi et al., 2010).

Halal-related Programmes: Some universities in Malaysia has setting up their own Halal institute to cater and to complement the Halal research and development, while some offering Halal studies in diploma, degree, master and $\mathrm{PhD}$ level so that industry can generate the well-trained personnel in every area of expertise in Halal industry. Universiti Putra Malaysia (UPM), Universiti Sains Islam Malaysia (USIM), International Islamic University Malaysia (IIUM), Universiti Malaysia Pahang (UMP), and Universiti Teknologi Malaysia (UTM) are among the universities that have their own Halal institution and Halal programmes for students (Ahmad et al., 2011; Hassan, 2011) There are also some government organization, non-government organization (NGO) and private companies that engage in promoting awareness of the consumers on Halal product through any means of promotional activities like Halal conference, Halal seminar, Halal auditor training, Halal forum and so on. However, from webpages of the institutions, companies and departments, those activities required tad expensive fees and limited at certain urban areas. All things considered, Figure 1 illustrates the theoretical framework of the study.

Figure 1: Theoretical Framework of Awareness and Perception on Non-food Halal Producer

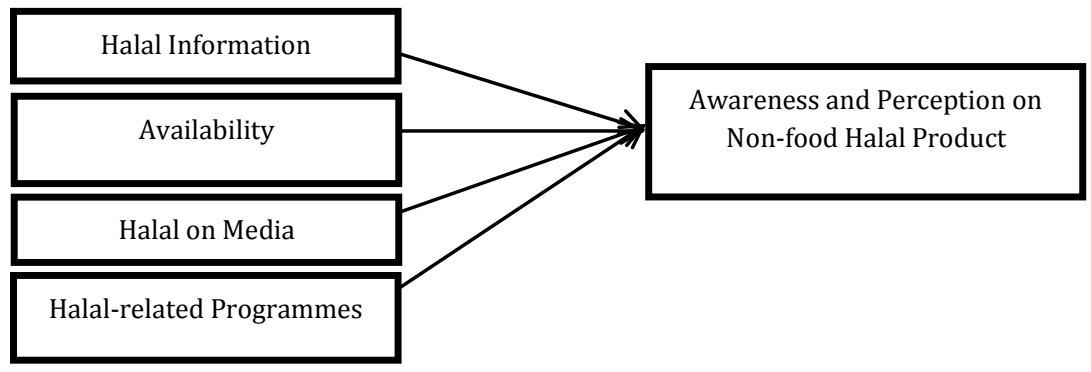

\section{Methodology}

Data for this study is collected through questionnaire. The sampling for this study is 236 government servants in the state of Selangor, Malaysia. The response of the questionnaire was measured by Likerttype Scale from 1 (strongly disagree) to 5 (strongly agree). The data collected then was analysed by the means of Cronbach reliability analysis, factor analysis, Pearson correlation and multiple regression analysis via Statistical Package for Social Science (SPSS) version 16 computer programme. For factor analysis, KMO and Bartlett test are used to measure the adequacy of the data. As suggested by Kaiser, KMO-Bartlett test that yields value over 0.5 is acceptable (Ridwan Shah et al., 2008). Cronbach reliability analysis is performed from the data of factor analysis component. The value according to Nunnally (1978) should equal or exceed 0.70 . To perform multiple regression analysis, Pearson correlation are to measure the correlation among the factors, the value is ranging from -1 to 1 , with positive value shows the positive linear correlation while negative value shows the negative linear correlation (Fah \& Hoon, 2009). Furthermore, multicollinearity test and Shapiro-Wilk normality test will be performed to ensure the multicollinearity and normality of the data. For multicollinearity test, if the Variance Inflation Factor (VIF) value is not exceeding 10 and Tolerance (TOL) value exceeding 1, it shows no multicollinearity. For Shapiro-Wilk normality test, if the $\mathrm{p}$-value is larger than $\mathrm{p}=0.05$, it indicate the normality distribution of the data. Multiple regression analysis is the measurement on calculating the contribution of every independent variable to the dependent variables simultaneously. Its common application is to measure the degree of correlation among variables (Galloway, 2004). Least square method is used to estimate the slope and the intercept of $y$-axis of the regression line while the coefficient of determination $\left(R^{2}\right)$ is used to examine the contribution of the independent variable to variance of dependent variable (Fah \& Hoon, 2009).

\section{Result and Analysis}

Profile of Respondents: The respondents comprised mainly of female, which is $67.4 \%$ and male $32.6 \%$. In terms of marital status, $70.8 \%$ are from married respondents, which are the majority group, while the 
single respondent and divorcee/single parent is $27.1 \%$ and $2.1 \%$ respectively. In the perspective of age, the majority of the respondents are between the age of 25 to 31 years old $(50.4 \%)$, with $45.8 \%$ having Bachelor Degree as their educational background, followed by Diploma/Matriculation/STPM/Foundation/A-Level holder which comprised of $34.7 \%$ and PMR/SPM holder comprised of $10.6 \%$. The analysis also demonstrates that most of the respondents earn RM 2100 RM 2800 per month (28.4\%) and RM 2801 - RM 3500 per month (22.5\%). The government servants in this study consisted from Kementerian Pelajaran Malaysia (KPM) as the majority group which is $21.6 \%$, followed by $11.4 \%$ respondents from Jabatan Kehakimandan Syariah Selangor (JAKESS) and 8.9\% respondents from Jabatan Pembangunan dan Perusahaan Negeri Selangor (JPPS).

\section{Factor Analysis}

KMO and Bartlett Test: From the Table 2 the value of KMO test is 0.598 . The value has exceeds the required value for factor analysis which is 0.5 . This means that the data can be used factor analysis for data reduction. From the Bartlett's Test of Sphericity, the observed value is 0.000, which is less than significance value 0.05 . This indicates that the data can be preceded for factor analysis.

Table 2: KMO and Bartlett's Test

\begin{tabular}{lll}
\hline Kaiser-Meyer-Olkin Measure of Sampling Adequacy. & .598 \\
Bartlett's Test of Sphericity & Approx. Chi-Square & 11488.864 \\
& Df & 3741.000 \\
& Sig. & .000 \\
\hline
\end{tabular}

Rotated Component Matrix: Table 3 shows the rotated component matrix of the awareness and perception of Muslim consumers on non-food Halal product. There are four factors that explained the factors of the awareness and perception on non-food Halal product with 27.85 total variations. The value of factor loading of 0.5 or more is kept as specified by Ridwan Shah et al. (2008) and Shaari and MohdAriffin (2010). Halal information $\left(X_{1}\right)$ explain $13.06 \%$, Availability $\left(X_{2}\right)$ explain 5.743\%, while Halal on Media $\left(\mathrm{X}_{3}\right)$ and Halal Programmes $\left(\mathrm{X}_{4}\right)$ explain $5.13 \%$ and $3.92 \%$ respectively. To interpret the independent component based on the varimax rotated matrix as given in Table 3 , it shows that the Factor $\mathrm{X}_{1}$ (Halal Information) delineates a cluster of relationship among the following attributes are 'I always bought Halal product'(HI 1), 'I know and familiar with Halal product' (HI 2), 'I used to read about Halal product' (HI 3), 'I satisfied when buying Halal product' ( HI 4), 'I used to heard about Halal product'(HI 5), 'Halal issues is interesting to me' (HI 6), 'I believe Malaysia is able to become Global Halal Hub' (HI 7), 'Halal product is safe and have a good quality' (HI 8), 'Halal product make feel secure and confidence when performing my prayer or performing Hajj' (HI 9), 'Halal product is allowed by Shariah for consumption' (HI 10), and 'I know about Halal product' (HI 11). The highly loaded variable in this factor suggests that it can be named 'Halal information'. This "Halal information" factor contributes around 13.06 per cent of the awareness and perception of Muslim consumers on non-food Halal product. Because factor $\mathrm{X}_{1}$ (Halal Information) has the highest eigenvalues and variance, (eigenvalue $=11.361$, variance $=$ $13.058 \%$ ) it is necessary to be considered as the major factor that influence the awareness and perception of non-food product.

The second factor delineates a cluster of relationship among 'I don't know any Halal cosmetics or Halal skincare' (AV 1), 'I don't know any Halal health product' (AV 2), and 'Halal skincare only available at small shops rather than major shopping complex' (AV 3). The nature of the second higher loaded variable on this factor suggests that it can be named as "Availability", which contributes about 5 per cent of the awareness and perception of Muslim consumers. It is the second higher eigenvalue and variance (eigenvalue $=4.997$, variance $=5.743 \%$ ). The third factor delineates a cluster of relationship attributes are 'I know the location and function of Halal Hub in Malaysia' (HM 1), 'A lot of websites and blogs talking on Halal issues and products' (HM 2), 'Halal only applicable to food, not for cosmetics, toothpaste or other non-food product' (HM 3), 'I heard about Halal product from radio' (HM 4), 'I know about Halal product from television' (HM 5) and 'JAKIM/HDC/Halal Journal/Halal Hub websites are user friendly' (HM 6). The nature of the loaded factor suggests that it can be named 'Halal on Media', which contributes around 5 per cent of the awareness and perception of Muslim consumers (eigenvalue $=4.4 .65$, variance $=5.132 \%$ ). The fourth factor delineates a cluster of relationship attributes are 'Bachelor, Master, Phd in Halal field is rare, if any, rarely employed' (HP 1), 'The fees for Halal seminar or conference is relatively expensive' (HP 2), 'Programmes related to Halal only available in Klang Valley, thus consumer outside Klang Valley have 
limited access of information' (HP 3) and 'Halal apprentice programme by JAKIM only limited to graduates from Islamic Studies and Food Science' (HP 4). The nature of the loaded factor suggests that it can be named 'Halal programmes', which contributed around 4 per cent of the awareness and perception of Muslim consumers (eigenvalue $=3.409$, variance $=3.918 \%$ )

Table 3: Rotated Component Matrix ${ }^{a}$

\begin{tabular}{|c|c|c|c|c|}
\hline Scale Item & $\begin{array}{l}\text { Halal } \\
\text { Information }\end{array}$ & Availability & $\begin{array}{l}\text { Halal on } \\
\text { Media }\end{array}$ & $\begin{array}{l}\text { Halal } \\
\text { Programmes }\end{array}$ \\
\hline $\begin{array}{l}\text { Halal Information } \\
\left(\mathrm{X}_{1}\right)\end{array}$ & & & & \\
\hline HI 1 & 0.710 & & & \\
\hline HI 2 & 0.663 & & & \\
\hline HI 3 & 0.644 & & & \\
\hline HI 4 & 0.620 & & & \\
\hline HI 5 & 0.588 & & & \\
\hline HI 6 & 0.556 & & & \\
\hline HI 7 & 0.551 & & & \\
\hline HI 8 & 0.544 & & & \\
\hline HI 9 & 0.543 & & & \\
\hline HI 10 & 0.533 & & & \\
\hline HI 11 & 0.532 & & & \\
\hline Availability $\left(\mathrm{X}_{2}\right)$ & & & & \\
\hline AV 1 & & 0.628 & & \\
\hline $\mathrm{AV} 2$ & & 0.625 & & \\
\hline AV 3 & & 0.541 & & \\
\hline Halal on Media $\left(\mathrm{X}_{3}\right)$ & & & & \\
\hline HM 1 & & & 0.616 & \\
\hline HM 2 & & & 0.573 & \\
\hline HM 3 & & & -0.546 & \\
\hline HM 4 & & & 0.545 & \\
\hline HM 5 & & & 0.525 & \\
\hline HM 6 & & & 0.515 & \\
\hline $\begin{array}{l}\text { Halal Programmes } \\
\left(\mathrm{X}_{4}\right)\end{array}$ & & & & \\
\hline HP 1 & & & & 0.609 \\
\hline HP 2 & & & & 0.600 \\
\hline HP 3 & & & & 0.530 \\
\hline HP 4 & & & & 0.513 \\
\hline Eigenvalue & 11.361 & 4.997 & 4.465 & 3.409 \\
\hline$\%$ of Variance & 13.058 & 5.743 & 5.132 & 3.918 \\
\hline Cumulative \% & 13.058 & 18.802 & 23.934 & 27.852 \\
\hline
\end{tabular}

Extraction Method: Principal Component Analysis

Rotation Method: Varimax with Kaiser Normalization

Rotation Component Matrix

Cronbach Reliability Analysis: The value shown through this data indicates the high reliability. The value of 0.761 is acceptable and exceeded the Nunnally's (1978) requirement which is 0.70 .

Table 4: Cronbach Reliability Analysis

\begin{tabular}{lll}
\hline Cronbach's Alpha & $\begin{array}{l}\text { Cronbach's Alpha Based on } \\
\text { Standardized Items }\end{array}$ & N of Items \\
\hline .761 & .790 & 24 \\
\hline
\end{tabular}

Pearson Correlation Analysis: Correlation analysis is to measure the degree of which the two variables are linearly correlated. Table 5 shows the correlation matrix between Awareness and Perception and the four factors; Halal information $\left(\mathrm{X}_{1}\right)$, Availability $\left(\mathrm{X}_{2}\right)$, Halal on Media $\left(\mathrm{X}_{3}\right)$ and Halal Programme $\left(\mathrm{X}_{4}\right)$. The value indicate that there is strong positive correlation between awareness and perception and Halal Information $\left(\mathrm{X}_{1}\right)$ and Availability $\left(\mathrm{X}_{2}\right)$ with value of 0.684 and 0.556 respectively $(+0.50<\mathrm{r}<+1.00)$. It also demonstrate that there is weak positive correlation between awareness and perception and Halal on 
Media $\left(\mathrm{X}_{3}\right)$ with value $0.273(0<\mathrm{r}+0.50)$. Besides, the table also shows the negative relationship between awareness and perception and Halal Programmes $\left(\mathrm{X}_{4}\right)$ with value $0.022(0<\mathrm{r}<+0.50)$. From the $\mathrm{p}$-value $(\mathrm{p}<0.01)$, it shows that all factors are significant except Halal Programme $\left(\mathrm{X}_{4}\right)$.

Table 5: Correlation matrix

\begin{tabular}{|c|c|c|c|c|c|c|}
\hline & $\begin{array}{l}\text { Awareness } \\
\text { Perception }\end{array}$ & $\&$ & $\begin{array}{l}\text { Halal } \\
\text { Information }\end{array}$ & Availability & $\begin{array}{l}\text { Halal on } \\
\text { Media }\end{array}$ & $\begin{array}{l}\text { Halal } \\
\text { Programme }\end{array}$ \\
\hline $\begin{array}{l}\text { Awareness \& } \\
\text { Perception }\end{array}$ & 1 & & & & & \\
\hline Halal & $0.684^{* *}$ & $=$ & 1 & & & \\
\hline Information & $0.000)$ & & & & & \\
\hline Availability & $\begin{array}{l}0.556^{* *} \quad \text { (sig } \\
0.000)\end{array}$ & $=$ & 0.006 & 1 & & \\
\hline $\begin{array}{l}\text { Halal on } \\
\text { Media }\end{array}$ & $\begin{array}{l}0.273^{* *} \quad \text { (sig } \\
0.000)\end{array}$ & $=$ & 0.056 & -0.020 & 1 & \\
\hline $\begin{array}{l}\text { Halal } \\
\text { Programme }\end{array}$ & $\begin{array}{l}0.022 \quad \text { (sig } \\
0.376)\end{array}$ & $=$ & 0.028 & -0.028 & -0.044 & 1 \\
\hline
\end{tabular}

Multicollinearity Test: The following table shows the result of multicollinearity. It is indicated from Table 6 that none of the VIF values exceed 10 and from the Tolerance values, all the values are exceeding 0.1 . From these values, it is concluded that there is no sign of multicollinearity exist in the model.

Table 6: Multicollinearity Test

\begin{tabular}{lll}
\hline Variables & Tolerance (TOL) & $\begin{array}{l}\text { Variance Inflation Factor } \\
\text { (VIF) }\end{array}$ \\
\hline Halal information & 0.996 & 1.004 \\
Availability & 0.999 & 1.001 \\
Halal on Media & 0.994 & 1.006 \\
Halal Programme & 0.996 & 1.004 \\
\hline
\end{tabular}

Shapiro - Wilk Normality Test: The Shapiro-Wilk normality test has proved the normality of the data distribution. According to Table 7 the $p$-value $(\operatorname{sig}=.085$ ) is larger than $p=0.05$, thus it is interpreted that the data distribution is normal and can be proceeded for multiple regression analysis.

Table 7: Shapiro-Wilk Normality Test

\begin{tabular}{|c|c|c|c|c|}
\hline & & $\begin{array}{l}\text { Shapiro-Wilk } \\
\text { Statistic }\end{array}$ & df & Sig. \\
\hline $\begin{array}{l}\text { Awareness } \\
\text { Perception }\end{array}$ & $\&$ & .989 & 229 & .085 \\
\hline
\end{tabular}

Multiple Regression Analysis: The multiple regression model can be expressed as follows:

$Y=\beta_{0}+\beta_{1} X_{1}+\beta_{2} X_{2}+\beta_{3} X_{3}+\beta_{4} X_{4}$

Where $\mathrm{Y}=$ awareness and perception

$\mathrm{X} 1$ = HalalInformation

$\mathrm{X} 2$ = Availability

X3 = HalalonMedia

X4 = HalalProgramme

Where $\beta_{0}, \beta_{1}, \beta_{2}, \beta_{3}, \beta_{4}=$ Parameters

Table 8 also shows that the Halal Information coefficient is 0.666 . It means that a unit increase in seeking or getting the Halal information of the consumers on non-food product, the awareness and perception on non-food Halal product will increase 0.666 units, at $\mathrm{p}<0.05$ ( $\mathrm{sig}=0.000$ ). This significant result suggests that the Halal information level of Muslim consumers on non-food product is significantly to the level of awareness and perception on non-food Halal product. The Availability coefficient is 0.558 . It means that a unit increase in availability of non-food product, the awareness and perception on non-food Halal product 
will increase 0.558 units, at $\mathrm{p}<0.05(\mathrm{sig}=0.000)$. This significant result suggests that the availability of non-food product is significantly to the level of awareness and perception on non-food Halal product.

Besides, the result also shows that the Halal on Media coefficient is 0.248 . It means that a unit increase in Halal non-food product in media, the awareness and perception on non-food Halal product will increase 0.248 units, at $p<0.05$ ( $\mathrm{sig}=0.000$ ). This significant result suggests that the media coverage of non-food product is significant to the level of awareness and perception on non-food Halal product. The table also demonstrated that the Halal programmes coefficient is 0.030 . It means that a unit increase in Halal programmes, the awareness and perception on non-food Halal product will increase by 0.030 units. The p-value shows that the Halal programme is not significant to the level of awareness and perception on non-food Halal product $(\mathrm{p}>0.05$, sig $=0.305)$.

Table 8: Coefficients ${ }^{\mathrm{a}}$ for Each Predictor Variable Using Enter Process

\begin{tabular}{|c|c|c|c|c|c|c|}
\hline \multirow{2}{*}{\multicolumn{2}{|c|}{ Model }} & \multicolumn{2}{|c|}{$\begin{array}{l}\text { Unstandardized } \\
\text { Coefficients }\end{array}$} & \multirow{2}{*}{$\begin{array}{l}\text { Standardized } \\
\text { Coefficients } \\
\text { Beta } \\
\end{array}$} & \multirow[t]{2}{*}{$\mathbf{t}$} & \multirow[t]{2}{*}{ Sig. } \\
\hline & & B & Std. Error & & & \\
\hline \multirow[t]{6}{*}{1} & (Constant) & 93.442 & .296 & & 315.325 & .000 \\
\hline & Halal & 6.920 & .300 & .666 & 23.066 & .000 \\
\hline & Information & & & & & \\
\hline & Availability & 5.662 & .292 & .558 & 19.364 & .000 \\
\hline & Halalon Media & 2.519 & .293 & .248 & 8.599 & .000 \\
\hline & Halal Programme & .312 & .303 & .030 & 1.029 & .305 \\
\hline \multicolumn{7}{|c|}{ a. Dependent Variable: Awareness \& Perception } \\
\hline
\end{tabular}

Table 9 shows the $\mathrm{R}^{2}$ and Adjusted $\mathrm{R}^{2}$ value of the regression model using the variables from factor analysis before. The $\mathrm{R}^{2} \mathrm{is} 0.834$ and significant at $\mathrm{p}=0.000$. This means that the independent variables 83 per cent of the variation in the dependent variable. It is interpreted that 83 per cent of awareness and perception of Muslim consumers on non-food Halal product has been significantly explained by the independent variables in the model. $\mathrm{R}^{2}$ value is an indicator of how well the model fits the data. However, $\mathrm{R}^{2}$ tends to somewhat over-estimate the success of the model when it is applied in the real world application, thus Adjusted $\mathrm{R}^{2}$ is calculated, which take $s$ into account the number of variables in the model and the number of observations (respondents). This Adjusted $\mathrm{R}^{2}$ is valued at 0.831 hence we can say that 83 per cent of the variation of independent variables explains the awareness and perception of Muslim consumers for non-food Halal product as independent variable. This means that only the remaining 17 per cent of the awareness and perception of Muslim consumers on non-food product is explained by other factors. Based on the result in table 8, the model can now expressed as follows:

$$
\begin{aligned}
& Y=\beta_{0}+\beta_{1} X_{1}+\beta_{2} X_{2}+\beta_{3} X_{3}+\beta_{4} X_{4} \\
& \text { AWARENESS \& PERCEPTION }=93.44+6.92 \text { Halallnformation }+5.66 \text { Availability }+
\end{aligned}
$$

2.52HalalonMedia + 0.31HalalProgramme

Table 9: Model Summary for Each Predictor Using Enter Process

\begin{tabular}{lcllll}
\hline Model & $\mathbf{R}$ & $\begin{array}{l}\text { R } \\
\text { Square }\end{array}$ & $\begin{array}{l}\text { Adjusted } \\
\text { Square }\end{array}$ & $\begin{array}{l}\text { R } \\
\text { Estimate }\end{array}$ & Error of the \\
\hline 1 & $.913^{\mathrm{a}}$ & .834 & .831 & 4.238 & \\
a. Predictors: (Constant), & Halal Programme, Availability, Halal \\
Information, Halalon Media & & & \\
\multicolumn{2}{l}{ b. Dependent Variable: Awareness \& Perception } \\
\hline
\end{tabular}

\section{Conclusion and Recommendations}

In this study, an attempt was made to investigate the factors of awareness and perception of Muslim consumers on non-food Halal product. The paper is based on data collected from government servant in Selangor. The study found that there are four factors that influence the awareness and perception of Muslim consumers on non-food Halal product that are extracted from factor analysis. The four factors are Halal Information $\left(\mathrm{X}_{1}\right)$, Availability $\left(\mathrm{X}_{2}\right)$, Halal on Media $\left(\mathrm{X}_{3}\right)$ and Halal programmes $\left(\mathrm{X}_{4}\right)$. From Pearson correlation analysis, all factors are significant except for Halal Programmes $\left(\mathrm{X}_{4}\right)$. It also an indicator that the Halal Programmes $\left(\mathrm{X}_{4}\right)$ is not a significant predictor to estimate the value of dependent variables 
which has been measured via multiple regression analysis. The other factors such Halal information $\left(\mathrm{X}_{1}\right)$, Availability $\left(\mathrm{X}_{2}\right)$ and Halal on Media $\left(\mathrm{X}_{3}\right)$ are statistically significant to contribute to the variation of the awareness and perception on Halal non-food products. This study implicates that regulators and stakeholders in the Halal industry are to take into considerations the measures that significantly contribute to the variation to the perception and awareness of the consumers. Players from Halal nonfood sector could initiate measures related to Halal information, Halal product availability and Halal information in media in order to build up awareness of consumers towards their products. This study can be considered as a first step to explore into more specific non-food products that include the other dimensions like purchasing intention, willingness to pay, consumer confidence, attitude, and many more.

\section{References}

Abdul Aziz, A., Amin, M. \& Isa, Z. (2010). The perception to choose Halal cosmetics products: An empirical study for Malaysian consumer. Paper presented at $6^{\text {th }}$ International Conference on Business, Management and Economics. Turkey: Yasar University.

Abdul Aziz, Y. \& Vui, C. N. (2012). The role of Halal awareness and Halal certification in influencing nonMuslims' purchasing intention. Paper presented at $3^{\text {rd }}$ InternationalConference on Business and Economic Research (3 ${ }^{\text {rd }}$ ICBER 2012) Proceeding, 1819-1830.

Ahmad, H., Fazullah, A., Borham, A. J., Hashim, H. \&Razak, M. (2011). Halal Studies in universities: A way forward to manage Halal business. Paper presented at International Journal of Arts and Sciences Conference, Austria.

Al-Mubarak, T. \& Osmani, N. M. (2009). Application of Maqasid al-Shariah and Maslahah in Islamic banking practices: An analysis. Retrieved from Research Gate, http://www.researchgate.net/publication/235988767_Applications_of_Maqasid_al-

Shariah_and_Maslahah_in_the_Islamic_Banking_Practices_An_Analysis/file/60b7d51754b8ebeec b.pdf

Anir, N. A., MdNasir, M. H. N. \& Masliyana, A. (2008). RFID Tag for Halal food tracking in Malaysia: User perceptions and opportunities. Paper presented at $7^{\text {th }}$ WSEAS International Conference on Telecommunications and Informatics (TELE-INFO'08), Turkey: Istanbul.

Ayanwale, A. B., Alimi, T. \& Ayanbimipe, M. A. (2005).The influence of advertising on consumer brand preference. Journal of Social Science, 10(1), 9-16.

Bahagian Penyelidikan JAKIM. (2009). Baranggunaandariperspektif Islam. Sinar Rohani, JAKIM, 11-13.

Che Omar, C. M. Z. (2013). Challenges and marketing strategies of Halal products in Malaysia. Interdisciplinary Journal of Research in Business, 3(2), 11-17

Could Halal cosmetic be developing into a new global C\&T niche market. (2010). Retrieved from IHIA website:http://www.ihialliance.org/news_detail.php?nid=103\&pgno=20\&

Esfahani, A. N. \& Shahnazari, A. (2013). Designing Halal and pure food model by emphasizing consumer behaviour management. Journal of Basic and Applied Scientific Research, 3(2), 574-578.

Fah, L. Y. \& Hoon, K. C. (2009). Introduction to Computer Data Analysis with SPSS 16.0 for Windows. Selangor: Venton Publishing.

Galloway, F. J. (2004). The secrets behind producing meaningful quantitative research: What every foundation official needs. Retrieved fromhttp://studentaffairs.unt.edu/sites/default/files/pdf/rap/Quantitative_Research_Tips.pdf

Halal Industry Development Corporation (HDC) website: http://www.hdcglobal.com

Halal Malaysia Week expected to rake deals of more than RM3.8 billion (2010, June 22), The Borneo Post, B11.

Hanzaee, K. H. \& Ramezani, M. R. (2011).Intention to Halal products in the world markets. Interdisciplinary Journal of Research in Business, 1(5), 01-07.

Hassan, H. (2010). Sistempensijilan Halal JAKIM dapatpengiktirafandunia. Berita Harian, 36

Hassan, H. (2011). UTM tawar Diploma Sains Halal. Utusan Online. Retrieved from http://www.utusan.com.my/utusan/info.asp?y=2011\&dt=1119\&pub=utusan_malaysia\&sec=Joh or\&pg=wj_01.htm

Hunter, M. (2012). The emerging Halal cosmetic and personal care market. Personal Care, 37-41. Retrieved

from http://works.bepress.com/cgi/viewcontent.cgi?article=1021\&context=murray_huntesiredir=1\&referer=http\%3A\%2F\%2Fscholar.google.com.my\%2Fscholar\%3Fstart\%3D30\%26q\%3 DHalal\%2Bawareness\%26hl\%3Den\%26as_sdt\%3D0\%2C5\#search=\%22Halal\%20awareness\%2 2

JAKIM Halal Division website: http://www.halaljakim.gov.my 
Kamaruzzaman, K. A. (2008). Halal cosmetics: Between real concerns and plain ignorance. The Halal Journal, 26-28.

Kettani, H. (2010). 2010 World Muslim Population. Proceedings of the $8^{\text {th }}$ Hawaii International Conference on Arts and Humanities, Honolulu Hawaii.

Malaysia, potential hub for Halal cosmetics. (2010). The Star Online. Retrieved from http://biz.thestar.com.my

Hisyam, M. M. (2006).The prospect of Halal concept for Muslim manufacturers.Retrieved from IKIM website, from http://www.ikim.gov.my/index.php/ms/artikel/7313-the-prospect-of-halalconcept-for-muslim-manufacturers.

Najib's take on Halal. (2010).The Halal Journal, 24-29

Nunnally, J. C. (1978). Psychometric theory. Ed.2.New York: Mc-GrawHill Book Company.

Rahim, S. \& Pawanteh, L. (2009).Media penetration and cultural indentity among young adults in Malaysia. European Journal of Social Sciences, 11(2), 225-23.

Ridwan Shah, N., Nooh, M. N., Nawai, N. \& Muhammad, H. (2008). Is Halal product are more expensive as perceived by the consumers? Muslimpreneurs challenges and opportunities in establishing a blue ocean playing field. Paper presented at $4^{\text {th }}$ International Conference on Business, Bangi: UNITEN. Retrived

from http://www.internationalconference.com.my/proceeding/ice2008_proceeding/PAPER_065_Hal alProducts.pdf

Shaari, J. A. \& MohdAriffin, N. S. (2010). Dimension of Halal purchase intention: A preliminary study. Paper presented at Eleventh International Business Conference, Australia. Retrieved from http://www.wbiconpro.com/18.Jamal.pdf

Shabanayagam, N. (2008). Blueprint to make Malaysia global Halal industry hub. New Straits Times, 4.

Sungkar, I. (2008). Muslim's awareness of Halal in the age of globalisation. The Halal Journal. Retrieved from The Halal Journal website.

Swidi, A., Wie, C., Hassan M. G., Al-Hosam, A. \&MohdKassim, A. W. (2010). The mainstream cosmetics industry in Malaysia and the emergence, growth and prospects of Halal cosmetics. The Third International Conference on International Studies (ICIS 2010),Sintok: Universiti Utara Malaysia.

Talib, Z., Zailani, S. \& Zainuddin, Y. (2010). Conceptualization on the dimensions for Halal orientation for food manufacturers: study in the context of Malaysia. Pakistan Journal of Social Sciences, 7(2), 56-61. doi: http://dx.doi.org/10.3923/pjssci.2010.56.61

Teng, P. K. \& Wan Jusoh, W. J. (2013). Investigating student awareness and usage intention towards Halal labelled cosmetics and personal care products in Malaysia. Paper presented at $4^{\text {th }}$ International Conference on Business and Economic Research (4th ICBER 2013), Indonesia: Bandung. 